\title{
What is conscience and why is respect for it so important?
}

\section{Daniel P. Sulmasy}

2008

Post-print.

The final version is available from www.springerlink.com, published as:

Sulmasy DP. What is conscience and why is respect for it so important?

Theor Med Bioeth. 2008;29(3):135-49. doi: 10.1007/s11017-008-9072-2. 


\begin{abstract}
The literature on conscience in medicine has paid little attention to what is meant by the word 'conscience.' This article distinguishes between retrospective and prospective conscience, distinguishes synderesis from conscience, and argues against intuitionist views of conscience. Conscience is defined as having two interrelated parts: (1) a commitment to morality itself; to acting and choosing morally according to the best of one’s ability, and (2) the activity of judging that an act one has done or about which one is deliberating would violate that commitment. Tolerance is defined as mutual respect for conscience. A set of boundary conditions for justifiable respect for conscientious objection in medicine is proposed.
\end{abstract}

Keywords: conscience, medical ethics, tolerance 


\section{WHAT IS CONSCIENCE?}

It should strike the reader as very odd that in all the recent debates about conscience, conscientious objection, institutional conscience, and the consciences of physicians, pharmacists, and patients, so little attention has been paid to understanding exactly what conscience is and what its importance might be. When definitions are offered, they are typically vague and unhelpful. For example, the American College of Obstetrics and Gynecology defines conscience as "the private, constant, ethically attuned part of the human character" [1]. Such definitions are not helpful.

\section{Retrospective and Prospective}

To begin a more in-depth discussion of what conscience is, one should first consider the idea that there are two broad ways to think about conscience-retrospectively and prospectively [2, pp. 315].

Conscience is often disturbed by things we have done or have failed to do. These are judgments of retrospective conscience, sometimes called judicial conscience. We make a judgment that what we did was, upon further reflection, wrongly decided. For example, a physician may have said something to a patient that she later realized was offensive. Or, as an intern, a physician may have practiced intubation on a newly dead patient without family consent. In retrospect, years later, this physician may have arrived at the judgment that this was wrong and may have resolved not to do so again and also to teach students and residents that they should not do so.

The emotion associated with the judgments of judicial conscience is guilt. Contrary to much contemporary pop psychology, all guilt is not bad. There are pathological forms of guilt, 
to be sure, and these must be avoided. In some cases they are signs of a major psychiatric illness such as major depression—a medical condition requiring treatment. But surely some instances of this emotion are signs of a healthy and mature conscience. The person who never experiences guilt may have a very underdeveloped conscience. Surely such a person would not be an ideal physician.

We sorely need a better understanding of the distinction between healthy and pathological guilt. That is a task for moral psychology that deserves greater attention, but it is not one I will discuss further in this essay.

Conscience is alerted not only by things we have already done, but also by things we anticipate doing or not doing. These are the judgments of prospective, or, as it is sometimes called, legislative conscience. For example, in the process of deliberating about whether to misrepresent the patient's diagnosis on a billing form upon the request of a patient, a physician may initially be inclined to do so but then begin to doubt that this is the morally right action. This prompting refers to prospective or legislative conscience. The topics that are of most concern in medical ethics today are about the legislative, prospective aspects of conscience, both by individuals and by institutions.

\section{Intuition and Conscience}

Noting that there are two types of conscientious judgment, however, still does not fully explain what we mean by conscience. One very common view of conscience is that it is a distinct mental faculty, an intuitive moral sense that determines the rightness and wrongness of actions.

This is the way Bishop Butler understood conscience-as a faculty with which each of us is endowed that "pronounces determinately some actions to be in themselves evil, wrong, unjust, 
[that] without being consulted, without being advised with (sic), magisterially exerts itself...” [3].

This is not an adequate theory of conscience. Conscience is not a little voice whispering to each of us infallibly about what we should do. Would that it were so simple. If conscience were nothing other than a sort of perfect perceptual intuitionism, all moral conversation would grind to a halt. The only thing moral philosophy could possibly say about morality would be “follow your conscience” [4]. I think we need to say more.

I am deeply skeptical about any form of act intuitionism as a theory of ethics. Our intuitions about particular cases will almost certainly differ. If they do, as they seem to in the troubling cases that confront us, such as abortion and physician-assisted suicide, then all we would be able to do would be to recognize that our intuitions differ. According to a theory of moral intuitionism, these differences could neither be explained nor challenged. This leaves open too many possibilities. My intuitions about what is right and what is wrong differ from those of the Janjaweed militia in Darfur. I want to reserve the right to challenge their intuitions.

If intuition has a role in moral decision making, in my view it would be at the level of what the medievals called synderesis. Peter Lombard, Bonaventure, and Aquinas all distinguished between conscientia and synderesis [5]. The latter was understood to be the capacity to apprehend the most basic moral principles-those principles that are not fully justifiable on the basis of other, more fundamental moral principles, but will be self-evident at least "in the sense that a person who reflects upon his nature will see that certain things are good for him and certain things are bad for him” [2, p. 61]. By synderesis, one might intuitively judge the truth of a very fundamental moral premise, such as, "that good is to be done and evil avoided” [6]. One might intuit that knowledge is a human good, or that life is a human good. Yet these intuitions are not acts of conscience, because while the object of synderesis is a form of 
moral knowledge, the object of conscience is something else.

\section{Affect, Motive, and Conscience}

If conscience is not moral intuition, nor is it merely a set of feelings. Mill, for instance, considered conscience to be a complex set of feelings that prevent us from doing wrong [7, pp. 73-75]. Anticipating Freud, he seems to have foreshadowed the concept of the super-ego-the irrational set of negative feelings that punish us in order to prevent us from violating the rules that have been set up by society to prevent our fundamentally selfish appetites from wreaking havoc. This is also an inadequate view of conscience. What I have said before regarding the role of emotions with respect to retrospective or judicial conscience also applies to the role of emotions in prospective or legislative conscience. Emotions are associated with conscience, but conscience is not reducible to those emotions. Nor need the activity of conscience necessarily be considered bad or unpleasant or contrary to our truest and deepest desires.

Conscience is also not to be confused with motive, whether that motive is an emotion or a belief. Conscience itself is not what moves us to act rightly or justly, even though the judgments of conscience may eventually lead to a motivational state.

\section{Principles and Conscience}

In clarifying what conscience is not, it is important, finally, to note that conscience is not constituted by or directed to a particular normative system or theoretical framework or set of principles. Conscience is not what makes one person a preference-maximizing utilitarian and the other a neo-Kantian liberal. Conscience, as a function of moral psychology supervenes upon all 
normative systems.

\section{A Contemporary View of Conscience}

One becomes aware of conscience in deliberating about particular cases. All deliberation about cases involves a conjunction of will and judgment that we commonly call 'conscience.'

As a conjunction of will and judgment, conscience, like Janus, has two faces. One face is turned toward its origin; the other is turned toward moral acts. The first face of conscience is an act of will; an assent to the truth that one should act morally. Conscience is thus rooted in a fundamental commitment to morality [8]. As such, it is almost impossible to suggest anything more important to the moral life than conscience. That we should act in accordance with our most deeply held beliefs about morality (that is, that we should act conscientiously), seems to be one of those precepts that comes to us intuitively, by synderesis. If we reject this premise, then there is certainly no point in discussing medical ethics, or ethics at all.

The other face of conscience is turned towards specific moral acts. This aspect of conscience is neither knowledge, nor a faculty of knowing, nor a conative (motivational) force moving a person towards good and away from evil [8]. The activity of conscience is a metajudgment that arises in particular moral deliberations. It is a judgment that a proposed act (or an act one has already accomplished) would violate one's fundamental moral commitments, including, importantly, a fundamental moral commitment to act with understanding.

As Fuss puts it, a person’s conscience “establishes a felt need or disposition to act in accordance with knowledge or belief, giving him a sense of personal integrity when he does the best he can, and a corresponding sense of inner failure, frustration, or guilt when, through some fault of his own, he fails to do so" [8]. The exercise of conscience is thus, as Fuss explains, 
accompanied by emotions such as satisfaction or guilt. Sometimes it is these emotions that trigger the judgment. But the act of conscience itself is a meta-moral judgment, not an emotion.

Conscience thus arises from a fundamental commitment or intention to be moral. It unifies the cognitive, conative, and emotional aspects of the moral life by a commitment to integrity or moral wholeness. It is a commitment to uphold one’s deepest self-identifying moral beliefs; a commitment to discern the moral features of particular cases as best one can, and to reason morally to the best of one's ability; a commitment to emotional balance in one's moral decision making, to being neither too hard nor too soft; a commitment to make decisions according to the best of one's moral ability and to act upon what one discerns to be the morally right course of action. Conscience arises from this meta-moral commitment to morality.

The acts of conscience, by contrast, are judgments. The judgments of conscience are judgments that what one has done or one is contemplating doing are in violation of this fundamental commitment to be moral. As such, conscience is the most fundamental of all moral duties - the duty to unite one's powers of reason, emotion, and will into an integrated moral whole based upon one’s most fundamental moral principles and identity.

This very fundamental nature gives conscience its primacy in deliberation about particular acts. “Thus,” says Hamlet, “conscience doth make cowards of us all” [9]. Conscientious living is not easy. Following conscience means following through on this fundamental commitment to be moral. To lack this fundamental commitment to moral integrity is to be less than fully human.

To sum up, then, we know by synderesis that we should be committed to morality itself and to acting and choosing according to our best judgment of the good and the right, to gathering the proper information, to obeying the moral rules of the system of morality to which we are 
fundamentally committed. Conscience arises from the inescapable conclusion that this is true. The activity of conscience is the judgment that an act about which one is deliberating, whether prospectively or in retrospect, would violate that commitment.

\section{CONSCIENCE AND MORAL ERROR}

\section{Akrasia}

Conscience helps us to make sense of the problem in moral psychology known as akrasia. The observation that human beings often do what they know to be wrong was first discussed extensively by Aristotle [10]. It also finds expression in the letters of St. Paul when he observes, "For I do not do the good that I want but the evil that I do not want” (Rom 15:19).

The activity of conscience is the recognition of the gap between one's knowledge of the good and the right, and the actual acts one has already undertaken or those about which one is deliberating. It is a sad fact that such judgments do not lead moral agents universally to choose and to do the good and the right. If knowledge of the good and the right led us infallibly to choose the good and the right, there would be no need for judgments of conscience because there would never be a gap between one’s fundamental moral commitments and one’s acts.

That which leads a person astray may be the influence of others or other strong desires. That which leads a person ultimately to choose the good and the right may be a stronger desire, or a prior commitment, or a belief, or the positive influences of others. The act of conscience itself, however, is the judgment that one is about to choose (or, in retrospect, has chosen) something that violates one's fundamental commitment to morality.

Conscience is thus not a faculty of judging right and wrong that is different from our usual ways of employing our faculties of reason, emotion, and will. Conscience arises from a 
commitment to engage in a "self-conscious activity, integrating reason, emotion, and will, in self-committed decisions about right and wrong, good and evil” [11, p. 14].

How can one fail to act on the judgments of conscience? This is the puzzle of akrasia. The explanations are many and varied. For example, to acknowledge the primacy of conscience but to reason that a particular conscientious judgment does not apply in a particular case, and so to act otherwise, might be an instance of "self-deception”. To allow unbalanced emotions to overwhelm the balanced judgment of reason and emotion, leading one to act against a conscientious judgment, would be “incontinence”. In general, choosing to do other than what conscientious judgment would prescribe is simply called "weakness of the will”.

\section{Erroneous Conscience}

Conscience can also err in its judgments. Adolf Eichman, for instance, apparently acted conscientiously. His conscience, by report, was troubled by the few exceptions he made for those Jews that he had allowed, solely because of personal connections with him and his family, to avoid the concentration camps he honestly felt they justly deserved [12, p. 122]. This suggests, rather obviously, that conscience is not an infallible moral guide.

Acknowledging the primacy of conscience does not imply a belief in the infallibility of conscience. Moral error is still possible through ignorance of important facts, or of the proper moral rules, or of one’s most fundamental self-identifying moral commitments.

It can also occur through faulty reasoning, emotional imbalance, or poor judgment. People can choose conscientiously and wrongly. Some such mistakes may be cognitive. One may have erred in one's estimation of the facts of the case as they pertain to the moral decision. Or one may be ignorant of the facts. One's moral premises may be in error. Or, one might have 
employed faulty moral reasoning, perhaps because strong emotions have clouded one's ability to decide.

The notion of conscience carries with it an obligation to form one's conscience correctly. This obligation finds juridical expression in the notion of due diligence. One is responsible for doing a certain amount of work to inform one's conscience, both with respect to the adoption of moral principles and with respect to accurate knowledge of the particulars necessary to decide a case correctly. One may therefore judge that certain individuals are culpable for their poorly formed consciences while others are not. Presumably we can judge that Eichman's conscience was poorly formed and that he was culpable for his actions. In other cases, however, this judgment will be much more difficult to make.

Despite the possibility of mistakes, over the centuries most moral philosophers have come to the conclusion that an erring conscience is binding [13-16, pp. 131-142]. This is quite logical. If conscience is derived from the fundamental moral commitment to choose the right and the good, then one is obligated to choose what one has determined to be the right and the good. One is only culpable in those cases in which one has failed to inform conscience properly, so that one's determination of the right and the good was culpably wrong.

\section{Conscience and Moral Complicity}

Central to many of the vexing cases about the consciences of health care professions is the relation between conscience and cooperation in what one has determined to be the wrong-doing of others. Everyone agrees that one should not be a moral accomplice to evil-doers. The bank guard who leaves the bank door open in order to facilitate a robbery by his best friend is an accomplice in the crime and has acted wrongly. 
Nonetheless, human beings need to cooperate with one another, and human beings are morally and intellectually finite. All of us are involved in wrongdoing. As Chesterton once observed, original sin is the only theological doctrine for which we have empirical proof [17, p. 19]. But how does one determine whether one is so closely involved in another's wrongdoing that one is complicit. Is one complicit in adultery if one continues to employ a nurses' aide that one knows is involved in an adulterous relationship, simply because one is providing the income that the aide uses to rent the hotel room, buy the flowers, etc.? When is one an accomplice in the wrongdoing of others and when must one simply accept the fact that all of us are morally fallible?

Obviously, conscientious judgments are required to determine whether one is complicit in the wrongdoing of others, judgments that must be informed by the virtue of prudence or practical wisdom. While others have written on the general subject [18], the natural law tradition has developed a very complex and subtle set of principles for navigating such uncertain and often uncharted waters [19, 20, pp. 871-897]. The first judgment to be made is whether one shares in the intent of the one who is doing wrong. This is called "formal" cooperation and a well-formed conscience always ought to judge that such cooperation is morally wrong. So, for instance, if I claim that I am opposed to suicide and euthanasia, but I give someone information on how to obtain two grams of secobarbital over the internet, along with instructions about how to wash it all down with a fine Bordeaux, and I share in the intent of the person who commits suicide this way, then I am culpable even if did not myself prescribe the drug or supervise its administration. But what if one is only indirectly facilitating the wrongdoing? There can be no hard and fast rules for this determination. If one is only "materially" involved in the wrongdoing of another, not sharing in the intent to do wrong, one must consider issues such as the following 
[20, pp. 871-897]: (1) How necessary is one’s cooperation to the carrying out of the act? Could it occur without one's cooperation? The more likely that it could occur without one's cooperation, the more justified is one's cooperation. (2) How proximate is one to the act, in space and time and in the causal chain? The further removed one is, the more justified is one's cooperation. (3) Is one under any degree of duress to perform the act? Is someone compelling the act at gunpoint? Does failure to cooperate mean loss of livelihood and ability to provide for a family? The more duress one is under, the more justifiable is one's cooperation. (4) How likely is one's cooperation to become habitual. The less likely, the more justifiable. (5) Is there a significant potential for scandal? I am using scandal here in the technical sense of leading others to believe that the one who is providing the material cooperation actually approves of the act so that observers might thereby be led to think it morally permissible. The less the potential for scandal, the more permissible the cooperation. (6) Does one have a special role that would be violated by this action? The less one has special role responsibilities that potentially would be contravened by the act, the more justifiable it is. (7) Does one have a proportionately important reason for the cooperation? That is, is there some morally important good that will come about because of one's indirect cooperation? If so, one has a better justification for cooperation.

A good medical example of such justifiable, remote material cooperation is the use of vaccines derived from tissues obtained from electively aborted human fetuses. Even very conservative moralists who are opposed to abortion have judged that such cooperation is sufficiently indirect, the chance of scandal sufficiently low, and the proportionate good so significant, that the cooperation involved in the use these vaccines is morally justified [21].

Note, however, that the prudential judgment necessary to determine that cooperation is justified is itself a matter for conscience. Individuals will differ in their judgments. For 
example, some in the pro-life community (in my view extremists) have judged that the use of vaccines derived from tissues obtained from aborted fetuses constitutes an immoral cooperation in the act of abortion [22]. Still, I respect their conscientious views even as I try to persuade them that they have judged imprudently.

\section{Unscrupulousness and Scrupulosity}

The judgments of conscience are prudential. Like any other virtue, one can err on either side of the Aristotelian golden mean [23]. One can err by having too lax a conscience as well as by having too strict a conscience. The former is called unscrupulousness. The latter is called scrupulosity. How much diligence constitutes ‘due diligence' in forming one’s conscience around a particular decision? How remote must one's material cooperation be in deciding whether to work with others? Hitting the golden mean is even part of the training of a good house officer. How much information must one gather before making a medical decision? Some house officers cut too many corners. Others do more than is needed, to the detriment of themselves and perhaps even other patients and their fellow house officers. In the end, one wants a conscientious physician, not an unscrupulous (or lax) one and not one who suffers from excessive scrupulosity.

\section{INSTITUTIONAL CONSCIENCE}

Can institutions exercise conscience? Are hospitals human institutions to which we ought to extend the notion of conscience?

Hospitals were once thought of as marketplaces in which itinerant physicians set up shop temporarily and cared for patients. In recent decades, this view has undergone remarkable 
transformation [24]. As long ago as 1982, Pellegrino argued that the idea that moral agency in health care resided exclusively with doctors and nurses was "untenable” [25]. Medical decision making has now become extraordinarily complex, involving multiple members of the health care team, the patient, the family, the social workers, the ethics committee, the administrators, the managed care organization, and the government.

But does the multiplicity of individual agents somehow add up to one big moral agent? It may seem peculiar to attribute moral agency to organizations rather than to individual persons. However, health care institutions, as corporations, are considered persons at law, and have been considered moral agents by organizations like the Joint Commission for years [26]. But these legal and regulatory classifications aside, morally speaking, health care institutions do seem to possess all the features that one would attribute to moral agents.

They make decisions, and, as institutions, are worthy of praise or blame for those decisions [27]. They act intentionally. They "have structures by which in certain contexts acts by persons will count as acts by the organization,” and both the members of the organization and the society at large acknowledge the validity of these structures [28].

Further, health care institutions are much more than mere “aggregates” of persons [28]. They are not random collections of doctors, nurses, social workers, and other professionals thrown together in a building without a common purpose and identity that transcends each of them. In organizations that qualify as moral agents, the identity of the organization is not exhausted by merely tallying up the identities of the individuals. Organizations have an identity that is much more than the sum of their constituent parts. For example, when the nursing shift changes, the University of Chicago Hospital is still the University of Chicago Hospital. If the entire Section of Dermatology suddenly quits, to enter private practice to do nothing but give 
botox injections, the University of Chicago loses something, to be sure, but it is still the University of Chicago. The institution has an overriding identity and purpose that goes beyond its members.

Health care institutions seem to qualify as moral agents because they have this overriding purpose and identity. They exist to help the sick. They do this through the agency of persons who have sworn oaths to put their skills at the service of patients, thus sealing a common purpose for the institution with all the moral binding force that these oaths carry. The common purpose of a health care institution is specifically to satisfy the moral obligations of the actors who play the central role in the institution, namely, the health care professionals [27].

Health care institutions are thus true moral agents. They have an identity that is greater than the sum of the identities of constituent members of the group. Some have religious identities. Almost all have explicit mission statements. They act intentionally. They make decisions for which they may receive praise or blame. They have recognized institutional structures by which the decisions of some (e.g., the Board of Trustees, the CEO, the Dean of the School of Nursing, or the Chair of Medicine), count as the decisions of the institution. We can appropriately criticize any of these leaders for acting in their own best interests rather than the interests of the institution. They are authorized to make decisions on behalf of an institution that is greater than any one of them, and their decisions must not undermine the fundamental selfidentifying commitments of the institution.

Moreover, if health care institutions are moral agents, they must also be understood to have consciences. Institutional conscience, like the conscience of individuals, is Janus-faced. The conscience of an institution is rooted in the fact that it professes a set of fundamental moral commitments and it must act in accord with them. The conscience of an institution is exercised 
in making the moral judgment that a decision that it has made or is considering would violate those fundamental moral commitments. Health care institutions act intentionally as institutions. They receive praise or blame for the decisions they make. They must reason about these decisions. They must sort through the emotional experiences of their individual members in making decisions. They must make moral judgments. In so doing, the institution, if it is to be a truly moral institution, should pursue its goals, decisions, and actions with a fundamental commitment to moral integrity.

Like individuals, institutions can fail conscientiously through faulty reasoning, misplaced emotions, or poor judgment. In so doing, a hospital would join the ranks of other human institutions struggling for integrity in the midst of all the ambiguity of the moral world. Institutions can also fail to act upon their own conscientious judgments, either through reasoning by expediency, or by being overwhelmed by emotions such as panic or greed, or by weakness of the will. This is how institutions become caught up in the web of evil in the world.

All this would imply that health care institutions have consciences, at least by a strong analogy if not also in fact [29]. Conscience is a fundamental moral commitment on the part of a moral agent to moral integrity, involving a commitment to uphold fundamental moral precepts and moral identity and, based upon these fundamental moral commitments, to make use of reason, emotion, and will to arrive at proper moral judgments and to act on these judgments. By these criteria, health care institutions have consciences.

\section{CONSCIENCE AND TOLERANCE}

Moral knowledge is imperfect. Even a moral realist will acknowledge that although we might approach certitude regarding certain moral questions, moral reasoning has no empirical method 
of verification.

Accordingly, conscientious persons will disagree about a wide range of moral issues. My view is that we can declare a number of acts to be wrong with moral certainty (e.g., putting people in gas chambers to rid the world of "imperfect genes”, such as those associated with mental retardation or certain racial groups, is morally wrong). But with respect to a wide range of other moral issues we have less certainty. As we approach the application of our moral principles and rules to particular cases, we also have less certainty. This is not to say that there are no correct answers to these questions. Rather, given the imperfections of our moral knowledge and reasoning, we must acknowledge that disagreements are inevitable. Call this moral realism tempered by epistemic moral humility. In the end, this is the true basis for tolerance.

Conscientious persons thus can argue with each other about moral questions, and have good reasons for doing so. If the cause of disagreement is a fault in reasoning, and one can show one's interlocutor that a particular moral position is inconsistent with his or her previously espoused, fundamental, self-identifying moral principles, one should be able to convince a conscientious person to have a change of moral position. If the facts are different than what they appeared to be to someone, he or she might be convinced to change a moral position by learning certain empirical facts. But if the differences are at the level of fundamental self-identifying moral principles, sincere persons may reach an impasse on a particular case. This is how the most serious conflicts of conscience arise.

Respect for conscience is at the root of the concept of tolerance [30]. I define tolerance as mutual respect for conscience. Tolerance is not, in the narrow and negative terms of J.S. Mill, mere non-interference in the self-regarding actions of others [7]. The set of all purely self- 
regarding actions is probably an empty set.

A nation is not a pile of totally unconnected rationally self-interested atoms. Tolerance is a sign of respect for other persons to whom we are connected, not a consequence of our inherent disconnectedness. Nonetheless, people’s fundamental self-identifying moral commitments differ, and the conscientious moral judgments based upon them will also, of necessity, differ. Yet, conscience has deep primacy and commands deep respect. Conscience is the fundamental commitment to be moral; the fundamental commitment to respect others. People of conscience owe each other, first and foremost, respect for their consciences.

Without conscience, no morality is possible. To have a conscience is to commit oneself, no matter what one's self-identifying moral commitments, to respect for the conscience of others. This is tolerance.

\section{The Boundaries of Tolerance}

Tolerance, considered as mutual respect for conscience, entails that individuals be given a very wide berth in their moral decision making. Tolerance need not entail absolute forbearance in the face of moral differences between apparently conscientious people. Tolerance must have, as for any virtue, an Aristotelian mean.

An intolerant society is one that draws the berth of tolerance for differences in conscience too narrowly. A society that places too many acts outside the boundaries of tolerance for conscientious differences in belief is a "repressive" society. Repression, one should note, knows no allegiance to any particular political ideology. One can be repressive on the right and or on the left-a Nazi or a Stalinist.

By contrast, a licentious society is one that gives conscience far too wide a berth, a 
society in which "anything goes." The ideal, although it may be difficult to define, is one that gives conscience its proper berth of tolerance. Such a society is one we would plainly call tolerant.

The Boundaries of Tolerance in Health Care

The question we now face is how the berth of tolerance for conscientious moral differences in health care should be drawn? What kinds of differences in moral approaches to health care ought to be tolerated and what kinds ought not be tolerated?

As a general rule, one should exhaust every other alternative before compelling any practice that is based upon deeply held, self-identifying moral beliefs. Respect for conscience is critical to the notion of tolerance and to the notion of morality itself. Yet this is not to say that conscientious objections can never be trumped by other considerations.

I have suggested that there are at least three important questions to ask in sketching the boundaries of tolerance in health care [31]. For the purposes of this discussion, a 'practice' will be taken to mean a policy of action or of refraining from action with respect to some particular aspect of health care, based upon fundamental religious beliefs or other deeply held, selfidentifying moral beliefs. The three questions are:

1) Does the practice undermine or contradict the principle of tolerance itself?

2) Does the practice entail a substantial risk of serious illness, injury, or death for those who do not share the belief that is said to justify the practice?

3) Is the practice an action or a refraining from action?

These questions deserve some further explanation. 
1. Any practice that claims a conscientious exemption but contradicts the underlying basis of tolerance for conscientious differences can, it seems, be forbidden by a just and tolerant society. By undermining or contradicting the basis of tolerance, I mean that the practice for which defenders are seeking tolerance is itself intolerant-e.g., if it is based upon antipathy towards a person's fixed characteristics (such as race or gender) or mere dislike or disagreement with a competent person's deeply held, self-identifying beliefs and affiliations unrelated to the practice at issue. ${ }^{1}$ So, for example, it would be intolerant to refuse to treat a Jehovah's Witness for pneumonia simply because of an antipathy towards the Jehovah's Witness religion. It would not, however, contradict the basis of tolerance if a surgeon were to refuse to operate on a patient who would not allow blood transfusions.

It would seem unjust for a person to ask for tolerance for an intolerant belief. A moral system that tolerated intolerance would seem internally inconsistent. This, I think, establishes one firm boundary for tolerance.

2. If a practice entails a substantial risk of serious illness, injury, or death to the party that disagrees with the practice, there are grounds for considering whether the practice can justifiably be tolerated. However, since conscience, as I argued above, is so fundamental to morality, the grounds for contravening someone’s conscientious disagreement must be very strong. Therefore, it would seem, in general, that inconvenience, psychological distress, or mild symptoms would not be sufficient grounds to compel conscience. Rather, one would need to

\footnotetext{
${ }^{1}$ In a brief essay it is impossible to say much more. Specifying exactly when a practice for which proponents seek tolerance is itself intolerant is a complicated matter. But in a rough and ready way, the plain person can grasp the self-contradiction of certain demands for tolerance. For example, it seems obvious that it is contradictory for the Taliban to demand tolerance for their religious belief that no other religion be tolerated.
} 
demonstrate a likely and imminent risk of actual illness or injury to the party that disagrees with the practice.

So, for example, the fact that a patient might need to be transferred to another institution; might be upset that the doctor or nurse disagrees; or might continue to experience some amount of dizziness while attempting to find someone who agreed with his or her request would not seem to be sufficient grounds to compel the consciences of physicians and nurses. Symptoms should be treated symptomatically while awaiting the resolution of any conflict of conscience, provided that the symptomatic treatment is not itself a problem for conscience. But deep mutual respect for conscience demands that we ought to be willing to be inconvenienced, if necessary, for each other's sake.

A serious risk of injury or death, by contrast, likely would constitute grounds to compel conscience. This standard is analogous to that needed to forgo confidentiality under the Tarasoff precedent [32]. Respect for conscience, I suggest, is at least as important as the maintenance of patient confidentiality.

3. Finally, asking whether the practice at issue is an action or a refraining from action also seems morally important. As a general rule, substantially greater moral justification should be required to compel someone to perform an action in the name of tolerance than should be required to compel someone to refrain from an action in the name of tolerance.

For example, less justification should be required to prohibit physicians who feel a conscientious obligation to do so from proselytizing patients in the setting of the physicianpatient relationship than should be required to compel physicians to perform female circumcision (“genital mutilation”) on young girls in violation of their consciences. No one should object to a 
prohibition on physicians using the physician-patient relationship as a pretext for proselytizing patients. Far more moral justification should be required, however, to compel the performance of an action that an individual finds conscientiously objectionable.

Suppose that $50.1 \%$ of the population of the Netherlands were to adopt a form of Islamic belief that included support for female circumcision. Suppose that the judiciary of that society were to find that its constitution guaranteed a right to female circumcision, while not finding constitutional grounds to require the minority to perform this procedure on themselves or on their children. Ought such a society therefore compel the conscientiously objecting individual physicians that it licenses to perform that procedure, simply because that society has determined that there is a legal right to have it performed? Or ought that society compel conscientiously objecting physicians to refer those who seek this procedure to clinicians who would be willing to do so? This seems beyond the bounds of true mutual respect for conscience.

It would therefore seem that tolerant societies would set a very high threshold for compelling the performance of a practice in violation of conscience. Conscientious refraining from actions, when such restraint does not risk illness, injury, or death, and does not constitute traditional tort claims such as battery, assault, or libel, would not seem to rise to the level of sufficient grounds for compelling conscience.

\section{CONCLUSION}

I have attempted to illuminate the nature, scope, and importance of conscience. In particular, I have shown that respect for conscience is not a trivial matter. It is timely to begin to get clearer about the role of conscience in medical practice. On the basis of the understanding of conscience that I have set forth in this essay, it should be clear that one should not readily 
empower the state to compel its physicians to alienate themselves from their deepest moral convictions. True tolerance suggests the need for a wide berth of tolerance in medical practice. Issues of conscientious disagreement will only increase as medical knowledge begins to be used for a myriad of purposes other than treating disease. A projected height of five feet, eight inches is not a disease. Facial wrinkles are not a disease. Yet medicine is being asked to intervene in an increasing number of situations such as these, and more and more physicians will begin to express moral reluctance to use their medical skills to fulfill patient preferences for such interventions. At stake are conscientious disagreements about the nature and goals of medical care itself. As technologies advance, disagreements will arise about ideas as fundamental as the meaning of disease and the nature and goals of medicine. Such fundamental disagreements are likely to engender even more serious questions of conscience in the future than those that confront us today. 


\section{References}

1. ACOG Committee. 2007. Opinion No. 385, November 2007: the limits of conscientious refusal in reproductive medicine. Obstetrics and Gynecology 110: 1203-8.

2. D’Arcy, Eric. 1961. Conscience and its right to freedom. New York: Sheed and Ward.

3. Butler, Joseph. 1950. Five sermons preached at the Rolls Chapel and a dissertation upon the nature of virtue, 37-38. Indianapolis: Bobbs-Merrill.

4. Hunter, J.F.M. 1973. Conscience. In Conscience, eds. John Donnelly and Leonard Lyons, 5584. New York: Alba House.

5. Potts, Timothy C. 1980. Conscience in medieval philosophy. New York: Cambridge University Press.

6. Aquinas, Thomas. 1963. Summa Theologiae, Blackfriars ed. I-II, q. 64, a. 2. New York: McGraw-Hill.

7. Mill, John Stuart. 1975. On liberty. In John Stuart Mill: Three Essays, 5-141. New York: Oxford University Press.

8. Fuss, Peter. 1973. Conscience. In Conscience, eds. John Donnelly and Leonard Lyons, 35-50. 
New York: Alba House.

9. Shakespeare, William. 1994. Hamlet, III, I, 83, ed. Susanne L. Wofford, 82. New York: Bedford/St. Martin’s.

10. Aristotle. 1985. Nichomachean Ethics (trans: Terence Irwin), $1145 b 8$ ff. Indianapolis, Indiana: Hackett.

11. Callahan, Sidney. 1991. In good conscience: reason and emotion in moral discourse. New York: Harper.

12. Arendt, Hanna. 1963. Eichmann in Jerusalem. New York: Viking Press.

13. Aquinas, Thomas. 1963. Summa Theologiae, Blackfriars ed. I-II, q. 19, a. 5. New York: McGraw-Hill.

14. Kilcullen, John. 1988. Bayle on the rights of conscience. In Sincerity and truth: essays on Arnauld, Bayle and toleration, 54-105. Oxford: Clarendon Press.

15. Kolnai, Aurel. 1978. Erroneous conscience. In Ethics, Value, and Reality: Selected Papers of Aurel Kolnai, eds. Bernard Williams and David Wiggins, 1-22. Indianapolis: Hackett.

16. Donagan, Alan. 1977. The theory of morality. Chicago: University of Chicago Press. 
17. Chesterton, G.K. 1995. Orthodoxy. San Francisco: Ignatius Press.

18. Kamm, F.M. 1999. Collaboration and responsibility. Philosophy and Public Affairs 28:169204.

19. Keenan, James F. and Thomas R. Kopfensteiner. 1995. The principle of cooperation. Health Progress 76 (April): 23-27.

20. Grisez, Germain. 1997. Difficult moral questions. Quincy, Illinois: Franciscan Press.

21. Pontifical Academy for Life. 2006. Moral reflections on vaccines prepared from cells derived from aborted fetuses. National Catholic Bioethics Quarterly 6: 541-550.

22. Vinnedge, Debra L. 2005. “Aborted fetal cell line vaccines and the Catholic family: a moral and historical perspective, revised version of October, 2005.” http://www.cogforlife.org/fetalvaccinetruth.htm\#Summary. Accessed 17 April 2008.

23. Aristotle. 1985. Nichomachean Ethics (trans: Terence Irwin), 1106a26 ff. Indianapolis, Indiana: Hackett.

24. Starr, Paul. 1982. The social transformation of American medicine. New York: Basic Books. 
25. Pellegrino, Edmund D. 1982. The ethics of collective judgments in medicine and health care. Journal of Medicine and Philosophy 7: 3-10.

26. De George, Michael T. 1982. The moral responsibility of the hospital. Journal of Medicine and Philosophy 7: 87-100.

27. Smith, Michael D. 1982. The virtuous organization. Journal of Medicine and Philosophy 7: $35-42$.

28. French, Peter A. 1982. Collective responsibility and the practice of medicine. Journal of Medicine and Philosophy 7: 65-85.

29. Nairn, Thomas A. 2001. Institutional conscience revisited. New Theology Review 14 (May): 39-49.

30. Locke, John. 1983. A letter concerning toleration, ed. James H. Tully. Indianapolis: Hackett.

31. Sulmasy, Daniel P. 1997. Institutional conscience and moral pluralism in health care. New Theology Review 10 (Nov): 5-12.

32. Sulmasy, Daniel P. 2000. On warning families about genetic risk: the ghost of Tarasoff. American Journal of Medicine 109: 738-739. 